\title{
الصورة الذهنية عن المرأة المصرية
}

نادية حليم

يهدف هذا البحث إلى دراسة أبعاد الصورة الذهنية عن المرأة المصرية لاى عينة ممثلة

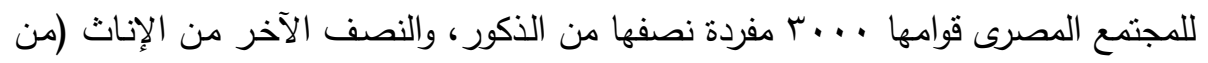

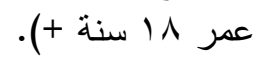
تناولت هذه الأبعاد السمات، الأدوار، وتأثير هذه الصورة الذهنية على العلاقات التهات

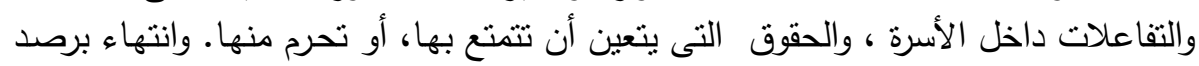

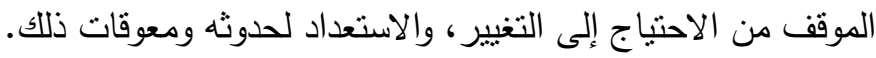

فى إطار اهتمام المركز بالتصدى للقضايا التى تعرقل مسيرة التتمية، قام

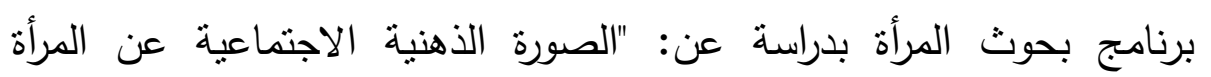
المصرية". هذه الصورة النى كونتها الثقافة والمجتمع عبر الزمن، وكرستها ولا لأل زالت تكرسها مؤسسات التنشئة. وهى صورة متعلمة ومكتسبة، وتتكل الخلفية

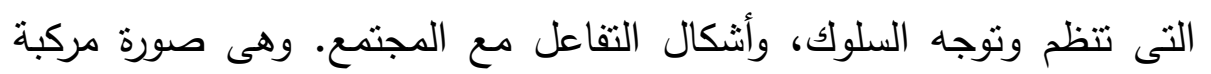

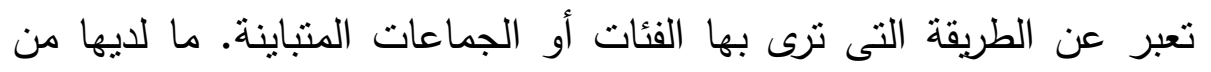

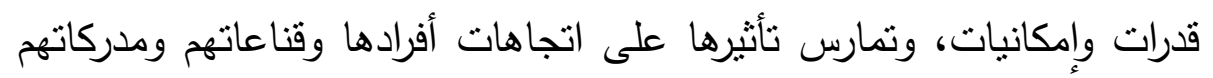
عن أنفسه وعن الآخرين.

* أستاذ علم الاجتماع، وتُعد برنامج بحوث المرأة، المركز القومى للبحوث الاجتماعية والجنائية،

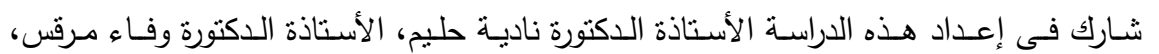

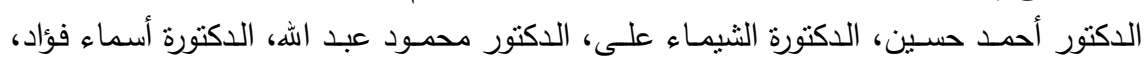

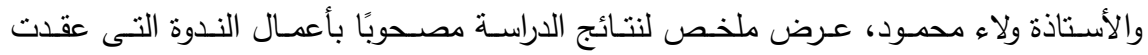
خصيصًا لمناقثة نتائجها.

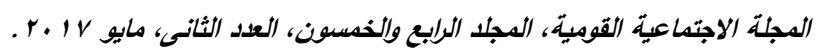


ومن الصعوبة أن نتصدى لدراسـة علاقات النوع الاجتماعى، أو قضـايا

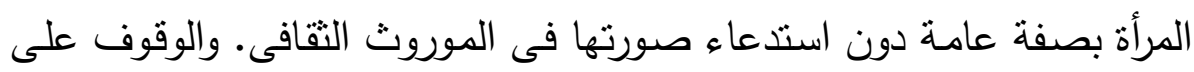

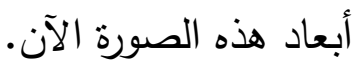

أجريت الدراسة على عينة ممثلة للمجتمع المصرى قوامها ـ ... مت مفردة،

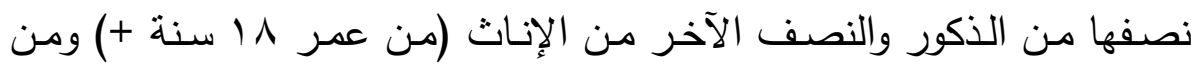

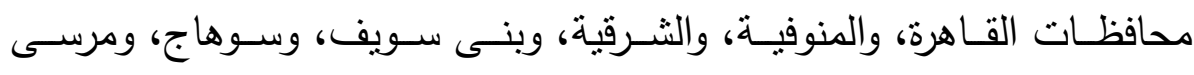

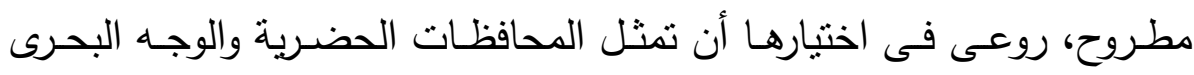

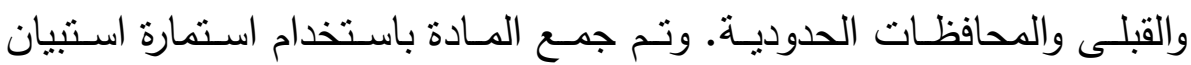
ومقياس صمم خصيصًا لأغراض الدراسة وتم تقنينه على يد عدد من الخبراء

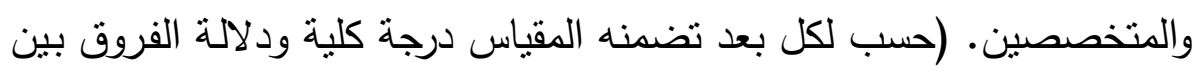

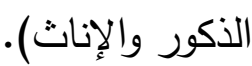
اهتمت الدراسة بالتعرف على أبعاد الصورة الذهنية عن المرأة المصرية

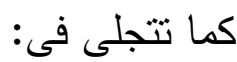

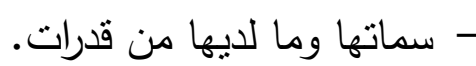
- الأدوار التى تصلح ولا تصلح للقيام بها. - ما تقرضه هذه الصورة من أنشكال العلاقات والتفاعلات داخل الأسرة. - الحقوق التى يتعين أن تتمتع بها أو تحرم منها. - وانتهاء برصد الموقف من الاحتياج إلى التغيير والاستعداد لحدوثه ومعوقات ذلك ^.

* تفاصيل العلاقة بين هذه الأبعاد ومتغيرات النوع، ومحل الإقامة، ومستوى التعليم والسن

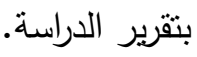


فيمـا يتعلق بالسمات والأدوار : يزخر التراث بالعديد مـن السمات التى

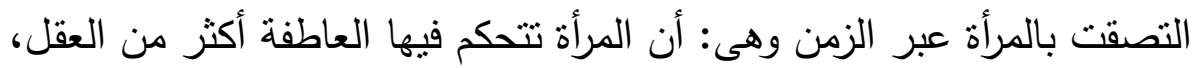

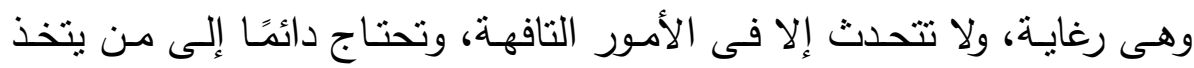

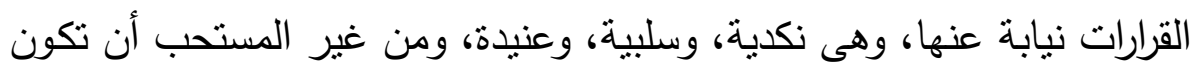
قوية الثخصية. وتوضـح النتائج: أن هنالك رفضًا - وإن كان فى الإجمال محدودًا - لعدد من هذه السمات، مع تفاوت نسب الرفض بين الذكور والإناث لصالح الإناث. ولم توجد فروق تذكر بين الريف والحضر • من أكثر السمات التى استمرت

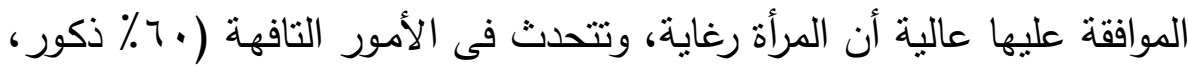

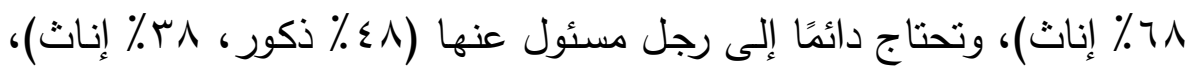

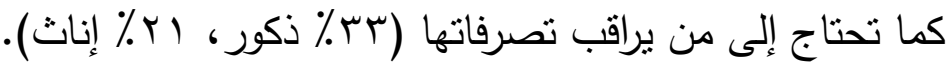

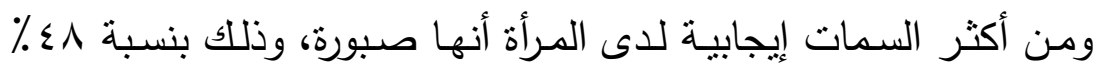

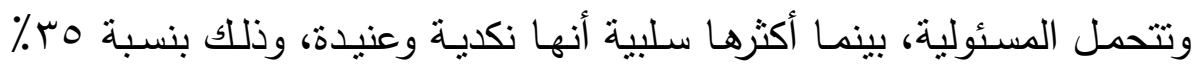

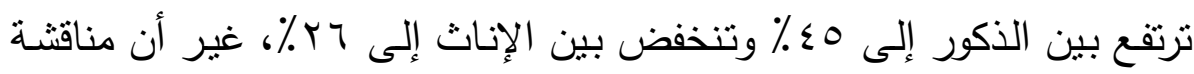

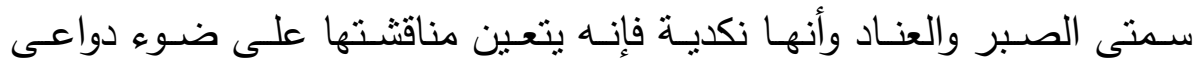

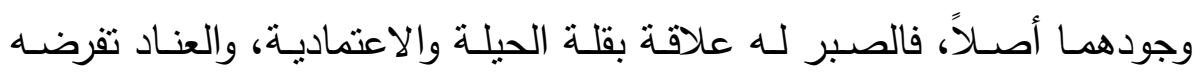

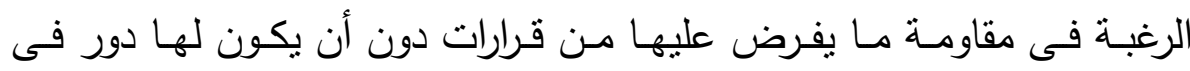

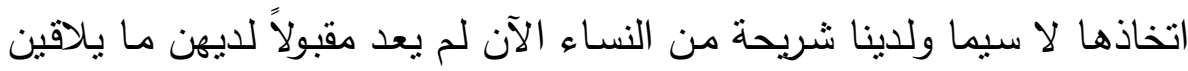

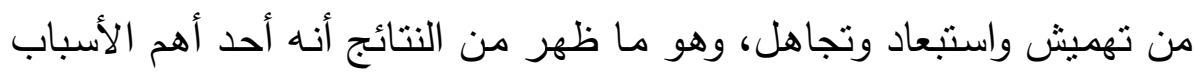

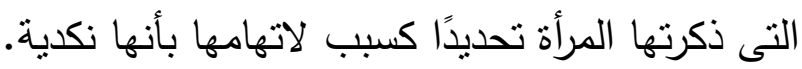

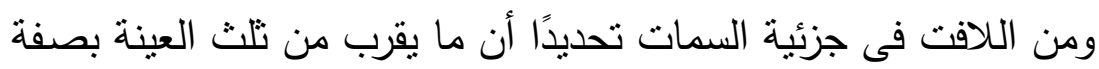

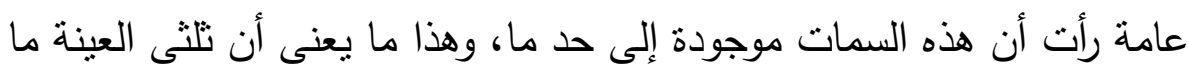

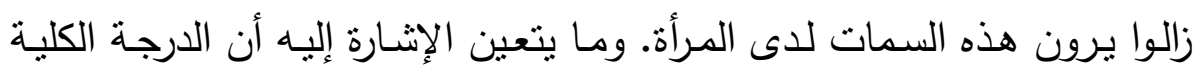


على المقياس فى جزئيسة السمات أظهرت فروقًا معنويـة بين الذكور والإنـاث لصالح رفض الإناث هذه السمات بصورة أكبر ·

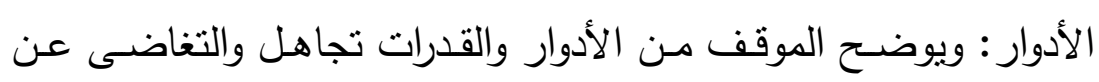

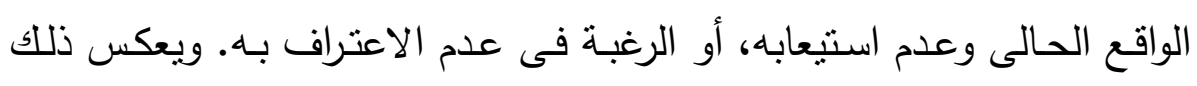

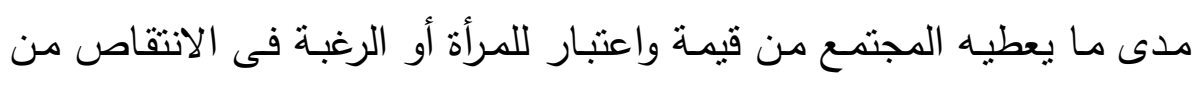
هذه القيمة والاعتبار .

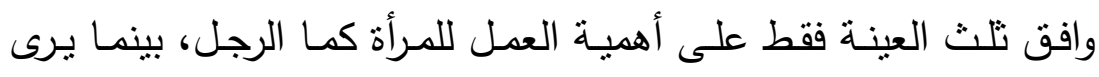

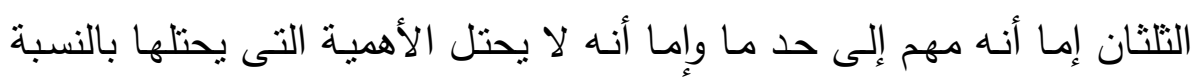

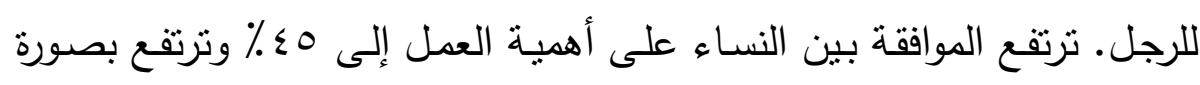

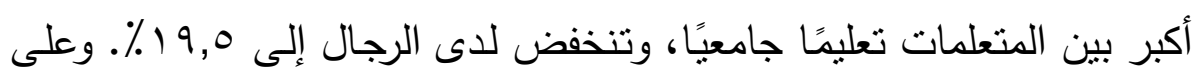

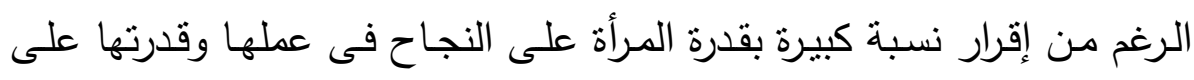

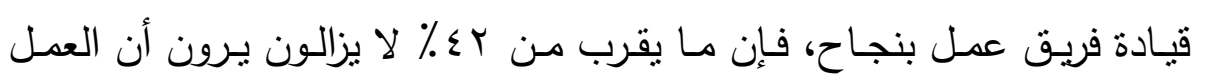

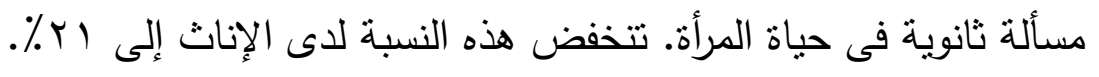

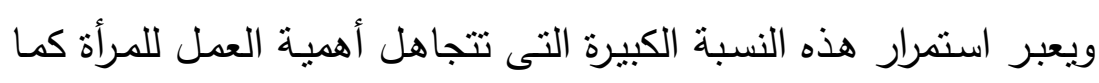

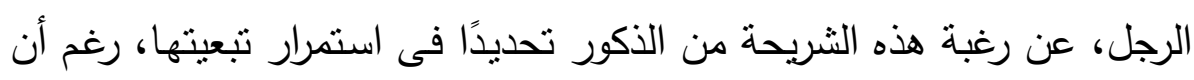

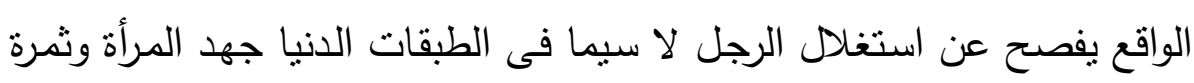
عملها، ورغم أن منهن من كسرت بالفعل هذه التبعية.

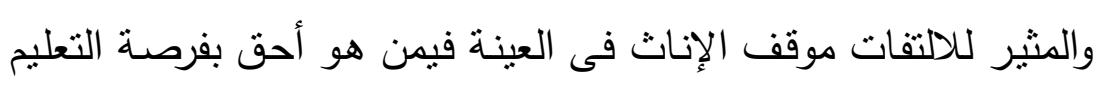

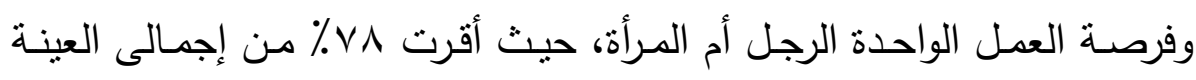

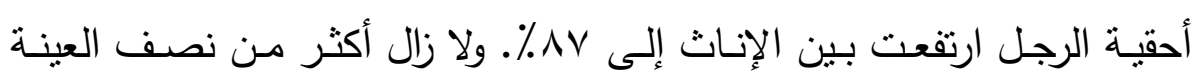

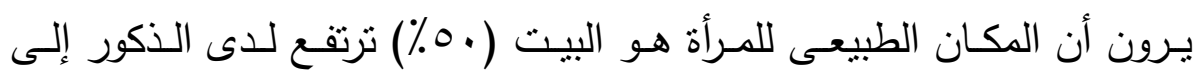

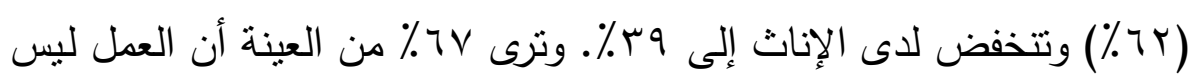




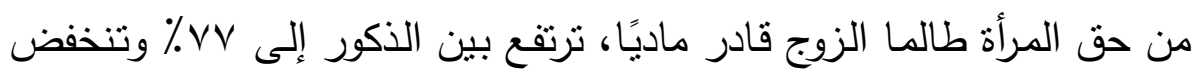

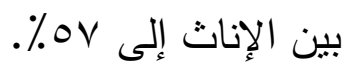

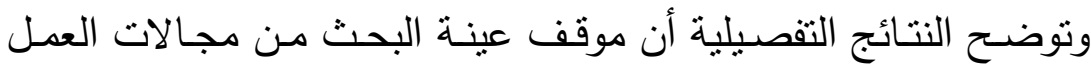

التى تتفوق فيها المرأة وصـلاحياتها وقدراتها لازالت تحكمها القناعات المبنية على الخصائص البيولوجية والتكوينية لكل من الذكر والأنثى أكثر من الاحتكام

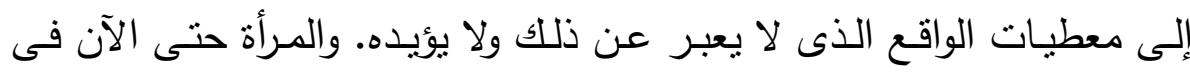

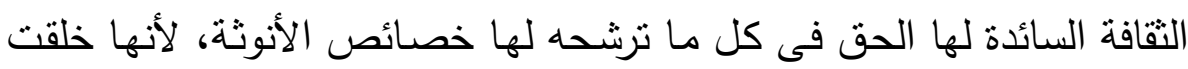

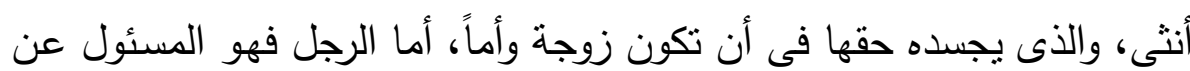

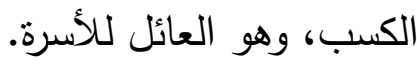

وفى ضوء هذه التقسيمة ظل ويظل العمل غير محورى فى حياة المرأة،

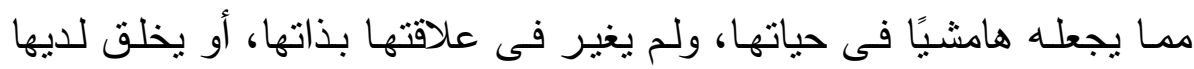

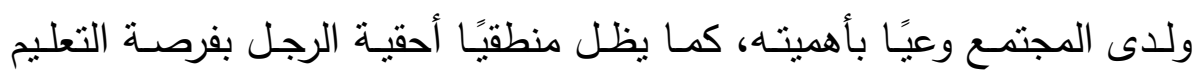

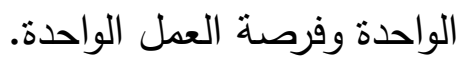

\section{وفى هجال العلاقات الأسرية}

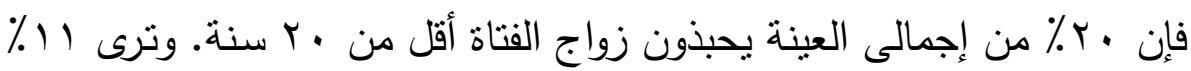

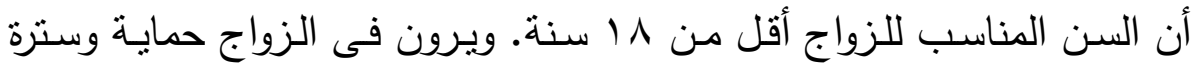

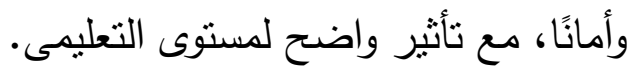

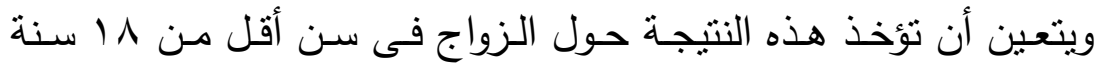

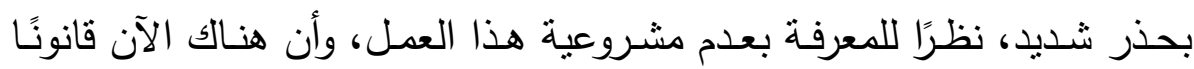

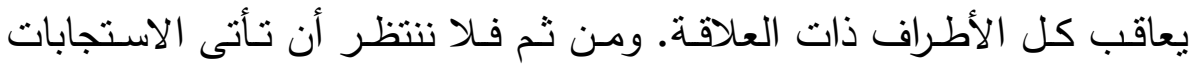

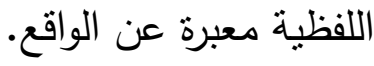


ومن الإيجابيات موافقة بץ\% من إجمالى العينة على المسئولية المشتركة

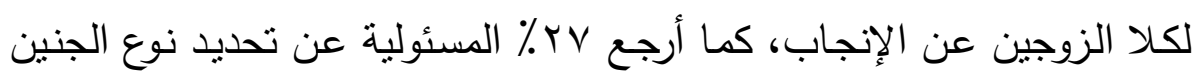
إلى الزواج، ويرى أكثر من نصف العينة أنها (حاجة بتاعت ربنا).

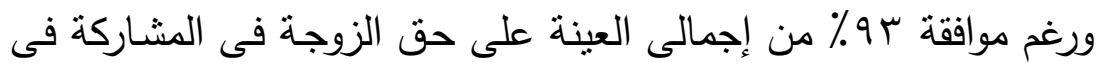

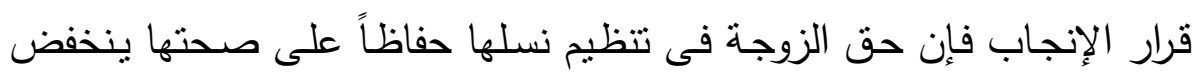

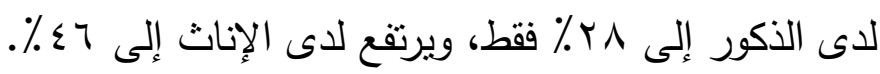

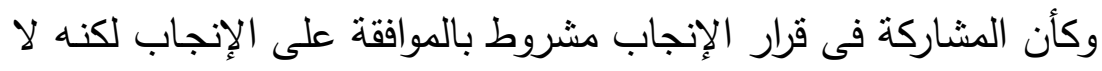

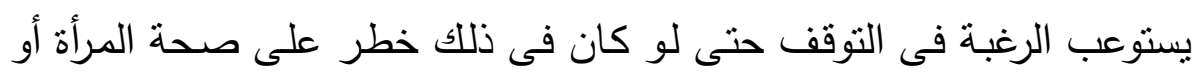

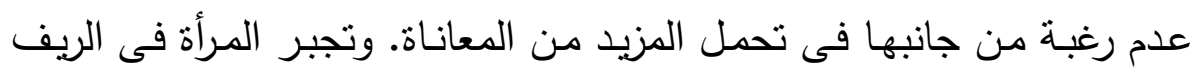

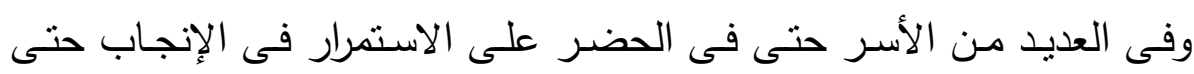
إنجاب الذكر .

- ل لازال • ـ ٪ من إجمالى العينة يرون العدد المفضل إنجابه من الأطفال ثلاثة

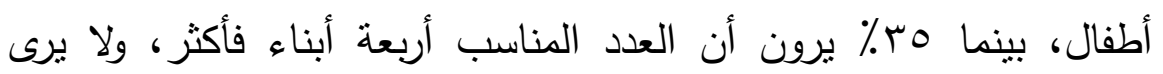

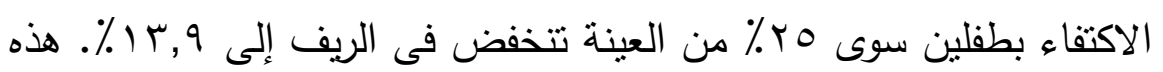

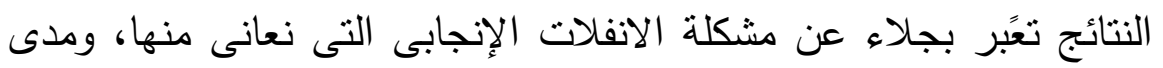

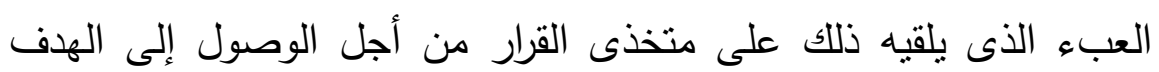

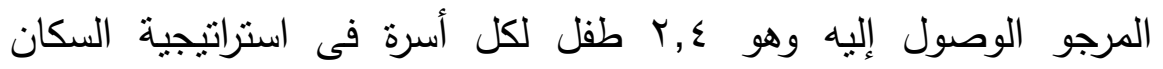
$r \cdot r \cdot / r \cdot 10$ - وترى VYr\% من عينة الريف الاستمرار فى الإنجاب طالما توفرت القدرة

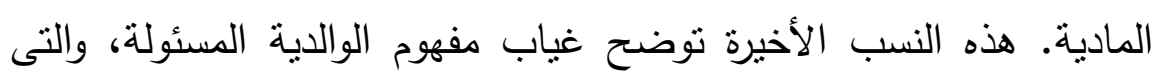

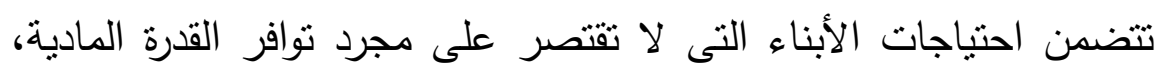

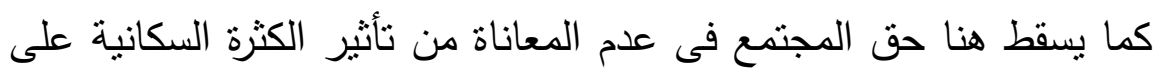


تدهور كل مرافق الدولة، وعلى إمكانية نوجيه الاستثمارات إلى التتمية وخلق

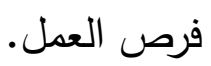

- ورغم موافقة آ٪ من العينة على اعتبار الإنفاق على الأسرة مسئولية

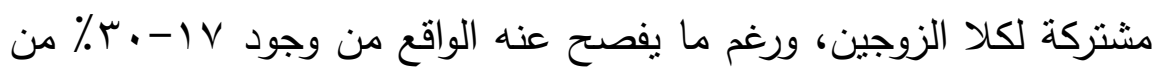

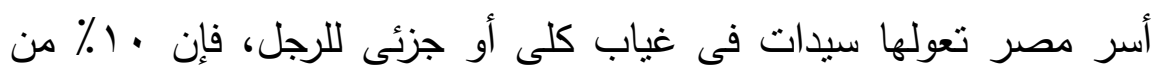

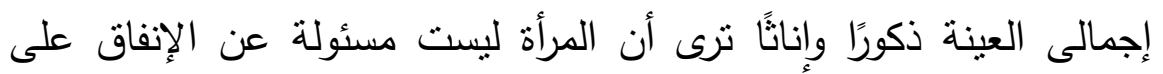

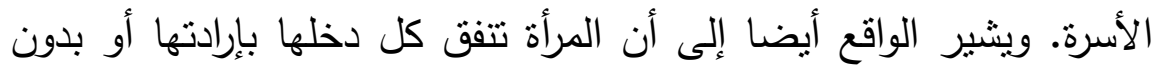

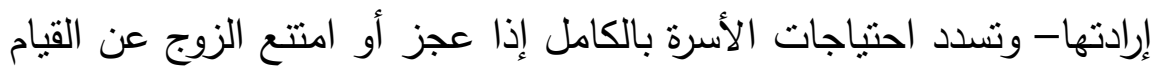

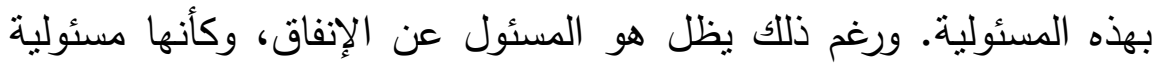

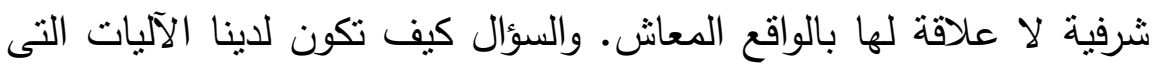

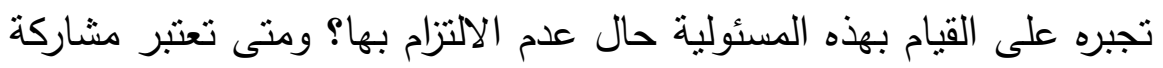

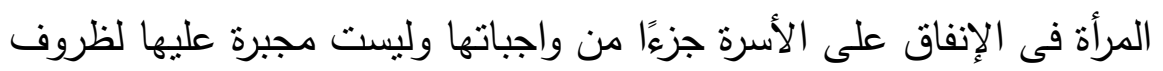

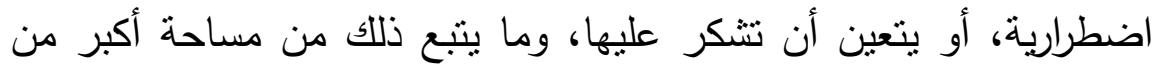

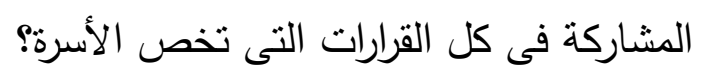

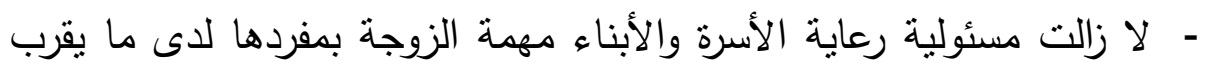
من نصف العينة، ولا يقر أهمية مشاركة الزوج فى أعباء البيت والأبناء

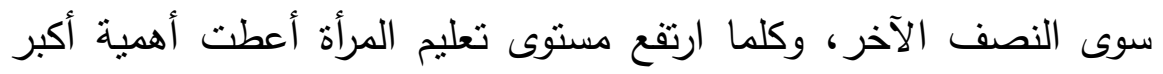

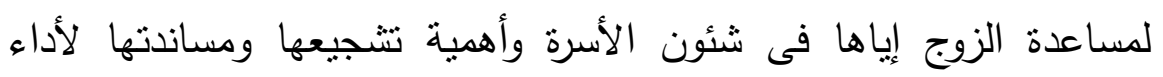
منطلبات عملها خارج الأسرة. - ويستمر الاتجاه الأكبر لاعتبار رعاية الزوج والبيت والأبناء من مهام المرأة فقط، ويعتبر استمرار المرأة فى عملها متوقفًا على قدرتها فى التوفيق بين التهاه

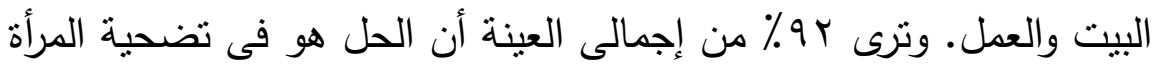


بعملها إذا لم تستطع التوفيق، وذلك بغض النظر عن النوع أو مستوى التعليم

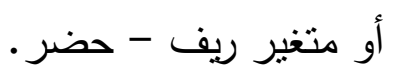

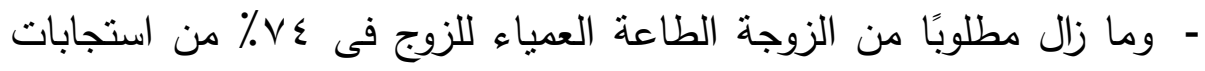

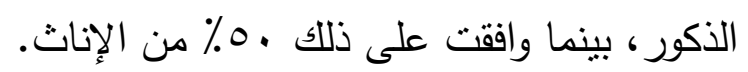

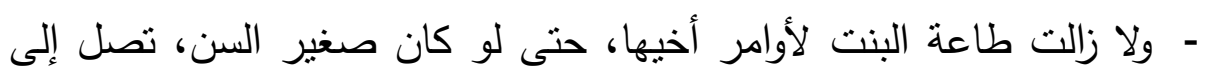

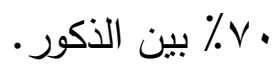

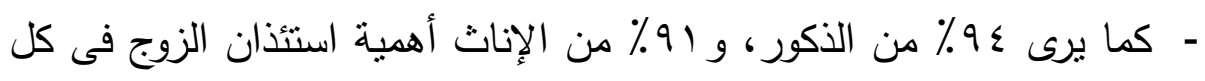

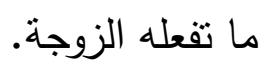

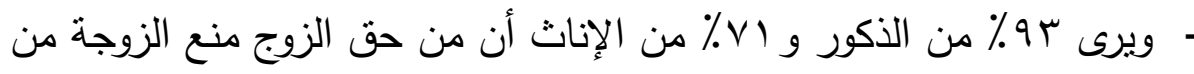

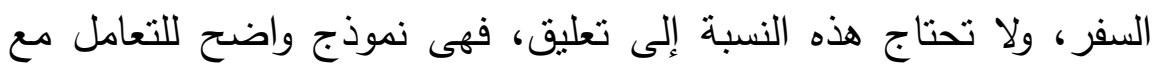

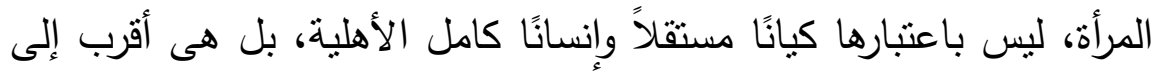

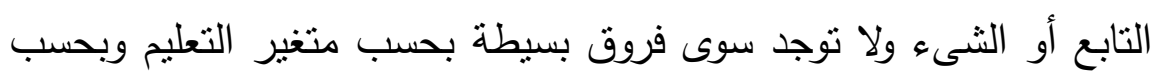
متغير ريف - حضر لصالح ارتفاع مستوى التعليم ولصالح الحضر .

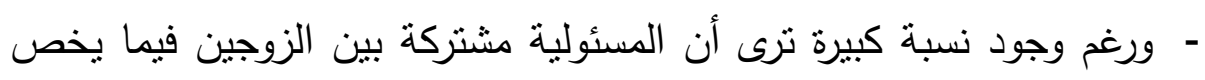

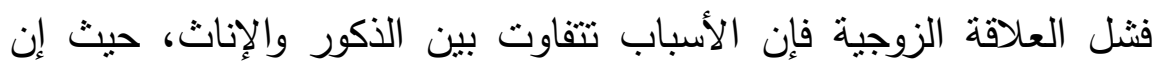

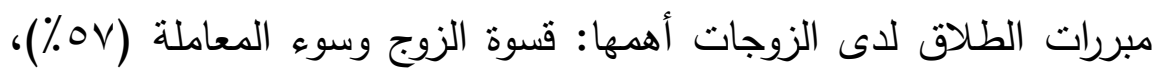

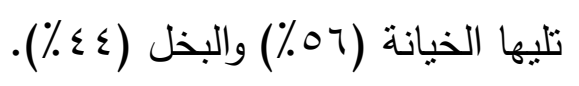
أما مبررات الطلاق لاى الأزواج فأهمها: النكد المستمر والخناق الناق

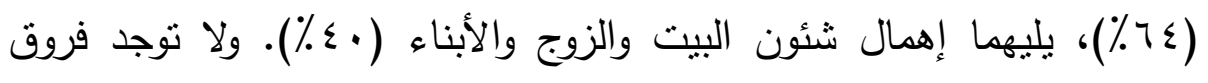

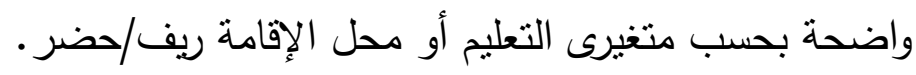

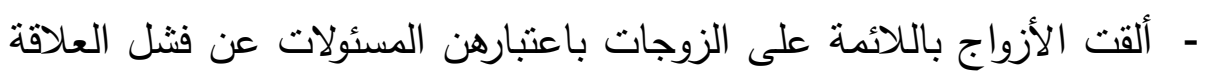

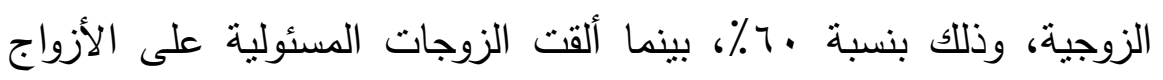

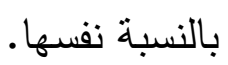




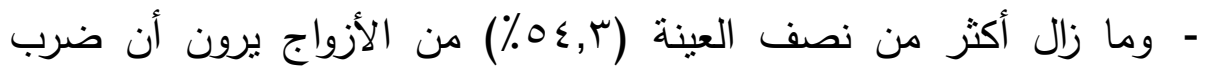

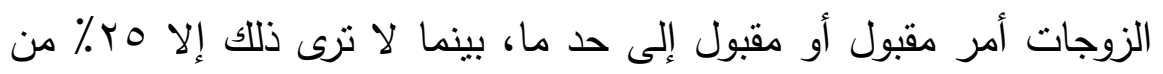

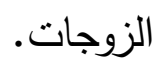

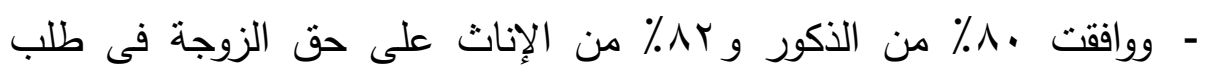

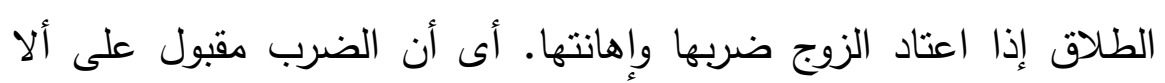
يكون اعنبادًا.

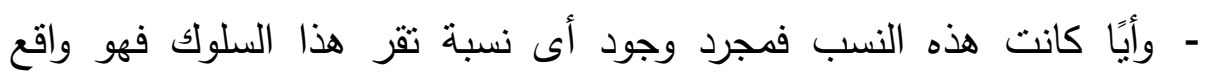

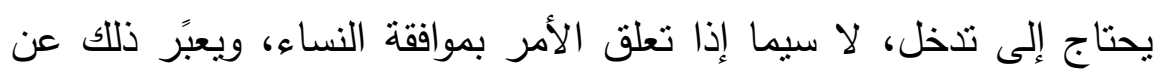

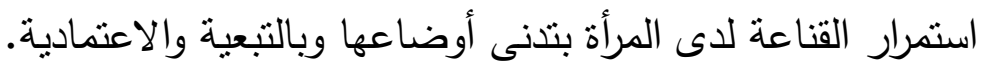

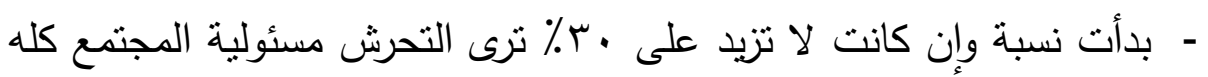

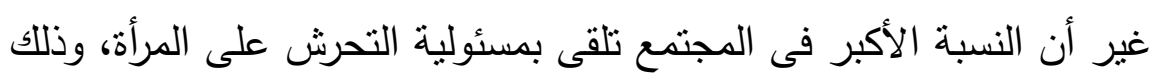

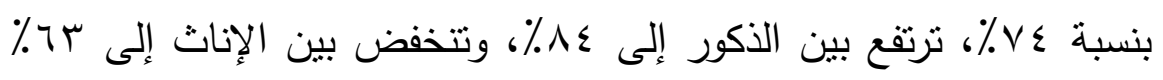

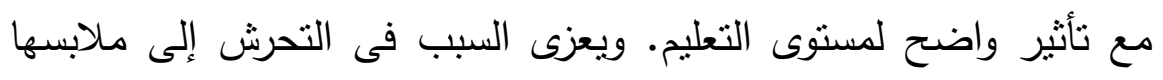

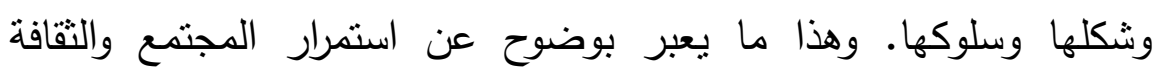

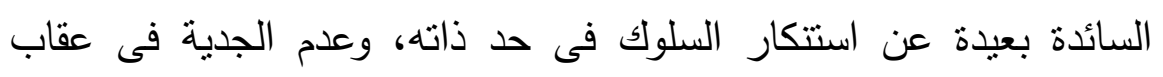

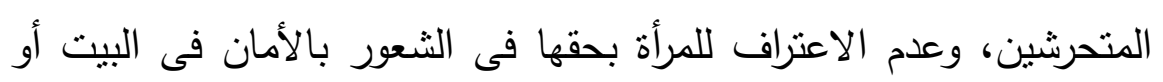

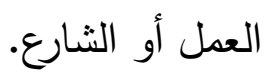

ويوضح الواقع الفعلى ويؤكد على وجود تضارب كبير بين الموقف

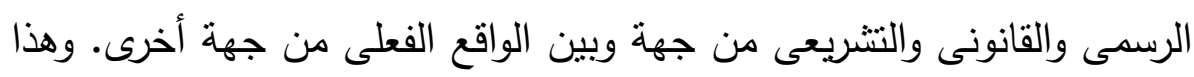

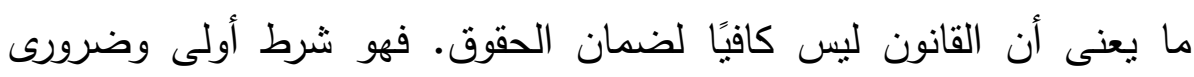

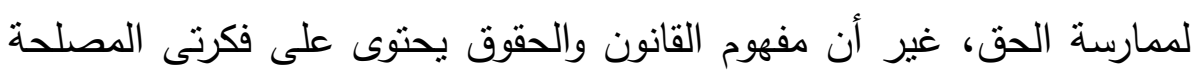
والإرادة الذى يجعل القانون قابلاً للتطبيق. 
وهذا ما يعنى أن إصدار الدساتير والتوقيع على المعاهدات، بل حتى لإنى

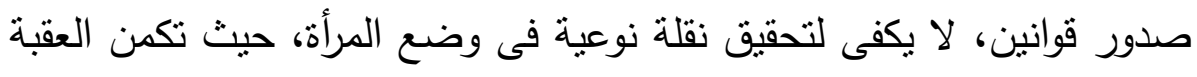

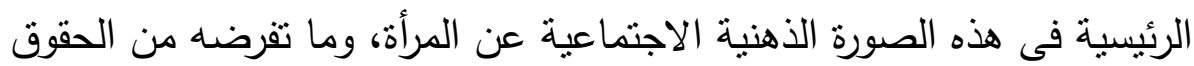
التى يتعين أن تتمتع بها أو تحرم منها. من القضايا المهمة التى أثنارتها هذه الدراسة حق المرأة فى الميراث. هذا

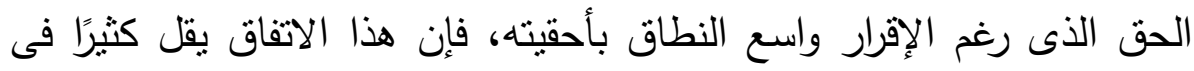

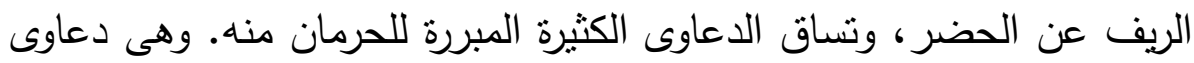

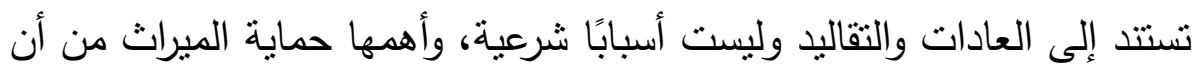

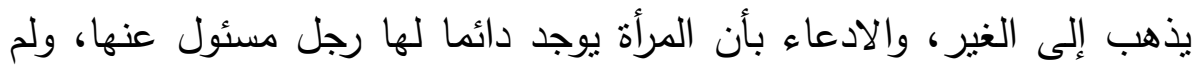

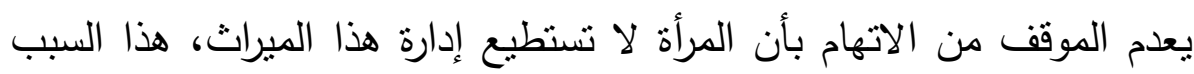

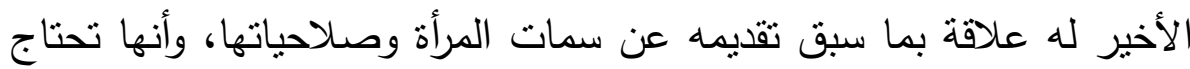

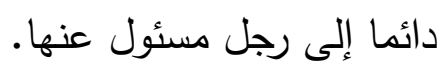

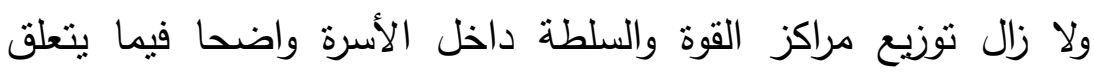
بالانخفاض الثنديد فى نسب قبول الزوجة رئيسة للزوج فى العمل، والذى لم الم تتعد نسبته بـ ٪ من إجمالى العينة. ولا توجد فروق تذكر بين الريف والحضر .

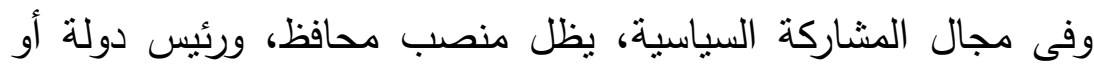

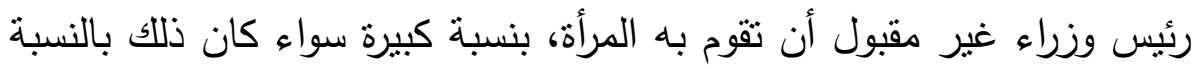

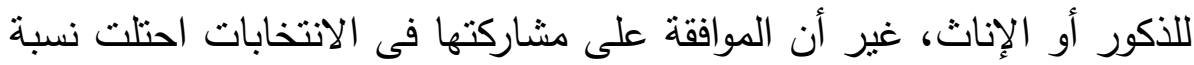

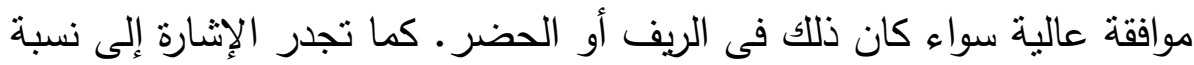

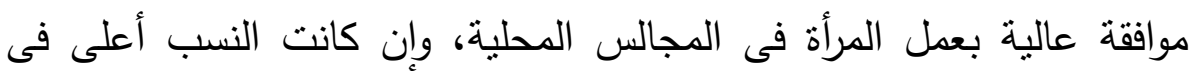
الحضر عن الريف، وبين النساء على الرجال.

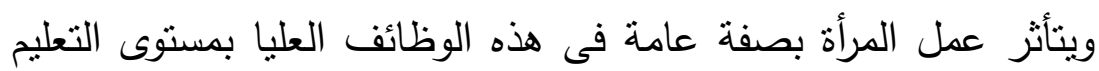

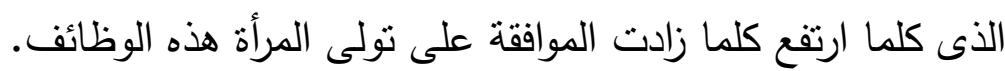


هذه النتائج توضح أن ثمة تحولاً. وإن كان محدودًا باتجاه رفض النظرة

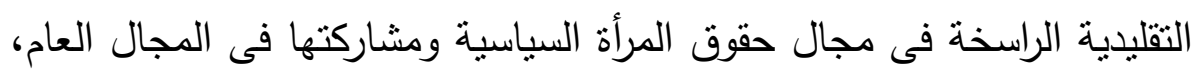

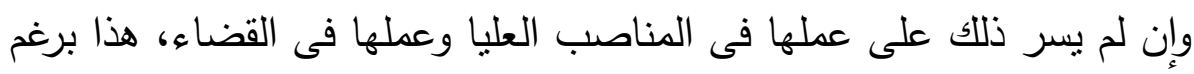
التحرك فى الموقف الآن وبصورة إيجابية مع الموقف الواضح للإبرادة السياسية الداعية للمرأة. ويبدو ذلك فى نولى المرأة منصب وزيرة فى مجالات كانت التهر حكرًا

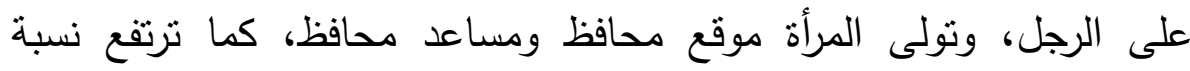

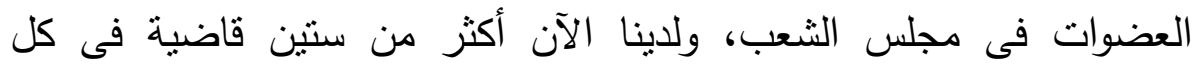

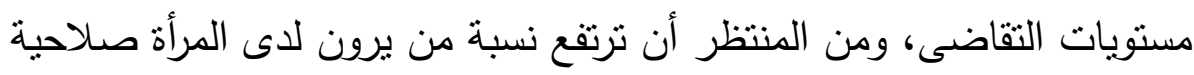

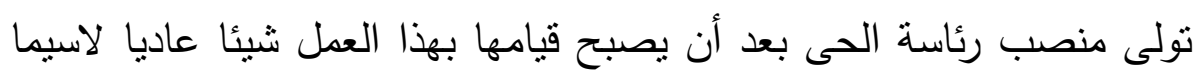
بعد تخصيص 0\% \% من هذه المحليات للمرأة .

ويعبر مجمل النتائج على جزئية الحقوق عن توجه إيجابى لمشاركة المرأة فى الحياة العامة والسياسية، غير أن ذلك لا يسرى على كل الجئه الجوانب،

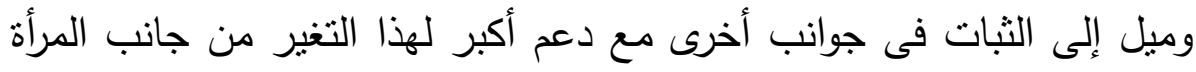

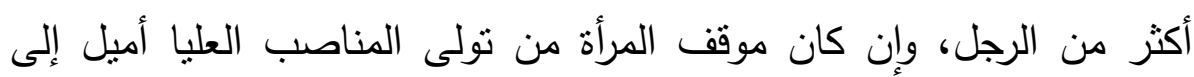

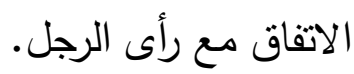

ويظل التغيير مطلبًا رئيسيًا من أجل تفكيك حزمة القيم السائدة والتفكير بأخرى تتحدث عن الواقع وتخاطب المستقبل. وعادة ما تعيش المجتمعات التقليدية - ونحن منها - نوعا من أنواطن أنواع الحداثة المزيفة، تتعكس على علاقات النوع التى يغلفها منطق التلفيق، وبدلا

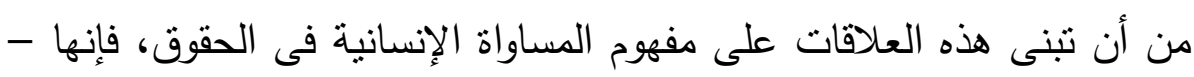

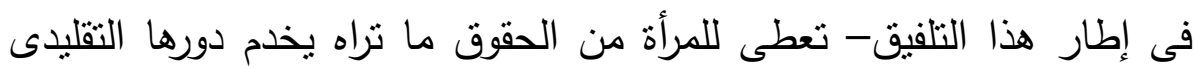
كأم. فالتعليم على سبيل المنال من أجل تحسين دورها فى نربية الأبناء، والصحة من أجل دورها الأمومى وهكذا ... 
وتبرز نتائج هذه الدراسة ميل المرأة أكثز من الرجل بشكل عام إلى

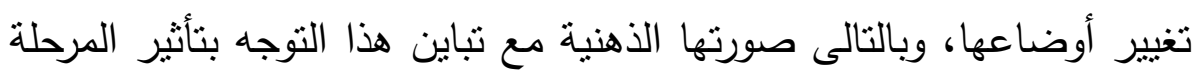
العمرية ومحل الإقامة ومسنتى التعليم.

وتعزو المرأة معوقات التغيير إلى الثقافة السائدة، والصورة النمطية، بينما

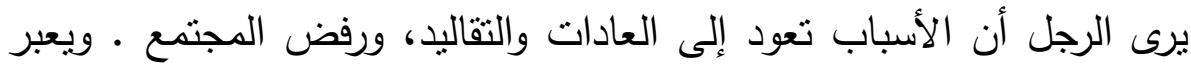

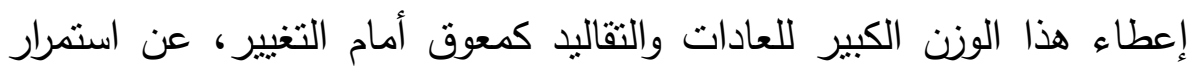

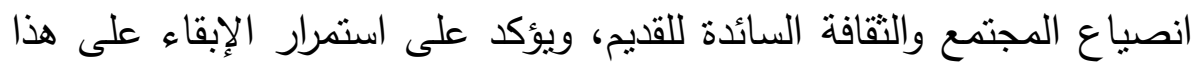
القديم تجنباً لحدوث الأزمات، واحتفاظا بمراكز القوة وتوزيع السلطة. ومن الناحية النظرية فإن الموقف من التغيير والخروج من الأنساق

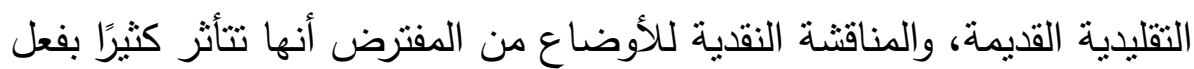

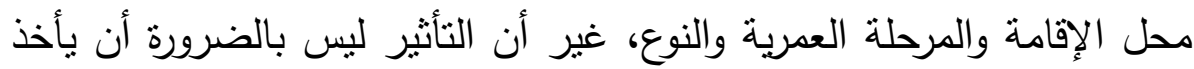

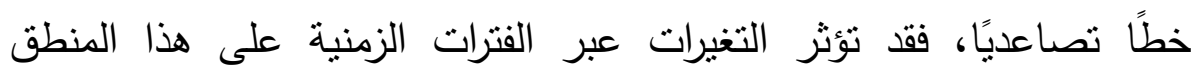

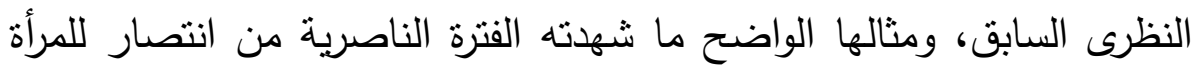

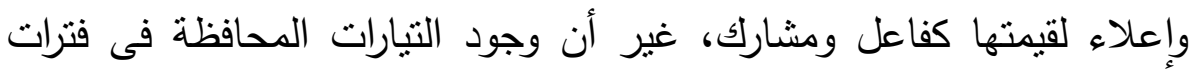

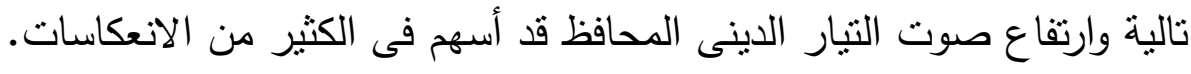

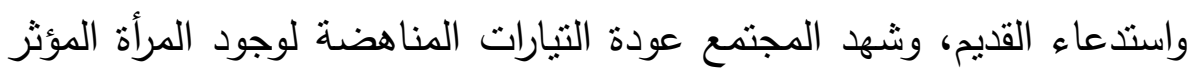
فى المجتمع من جانب بعض هذه التيارات.

\section{تسلمنا هذه الاراسة إلى عدة مؤشرات عامة وهى:}

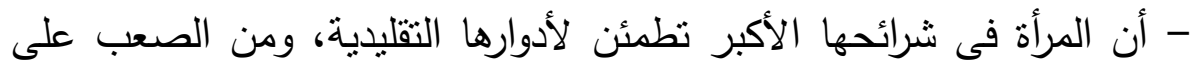

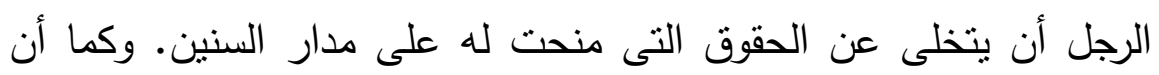

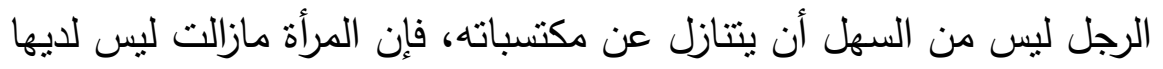
الاستعداد لدفع ثمن كسر نمطية هذا الفكر من أجل مجتمع أكثر عدالة. 
- تعد تبعية المرأة للرجل، وأولوية الرجل على المرأة من القيم التى مازالت تأخذ

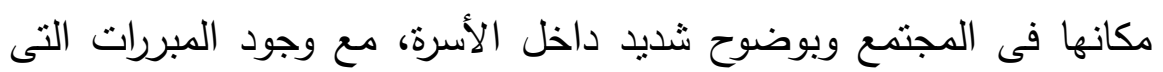
تبرر هذا التباين وتكرسه. - يزخر الموروث الثقافى للمجتمع المصرى بالكثثر من القناعات التى ترسم

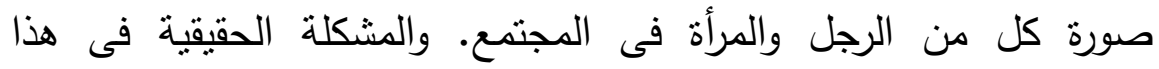

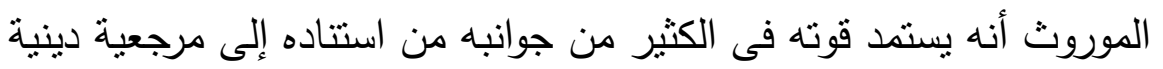
رغم الفهم الخاطئ لبعض نصوصه، يدعم هذا الفهم الخاطئ الفتاوى التى لنى تصدر بين الحين والآخر، غير أن عناصر التراث هذه ثبت عبد لدير التاريخ أنها ليست بذات القيمة والأهمية عبر كل الفترات الزمنية، ولكنها قد تخبو

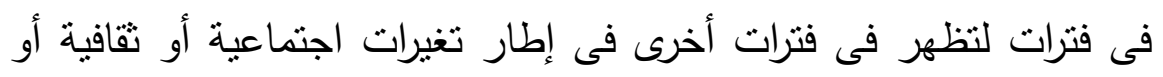

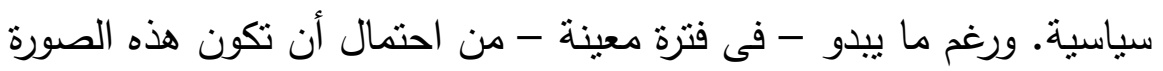

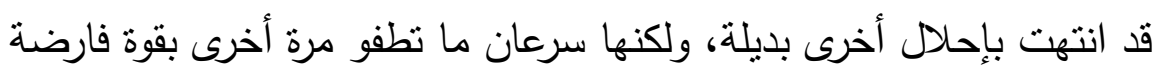

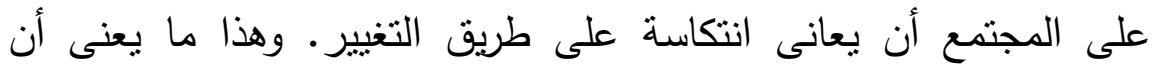

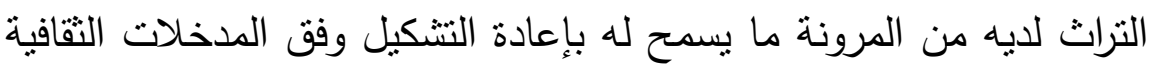

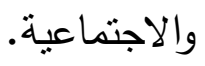
- ولا زالت قضايا تحريك وضع المرأة مرتبطة بالأحوال الاجتماعية

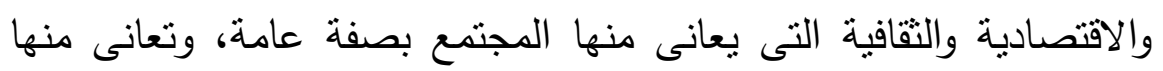
المرأة بصفة خاصة.

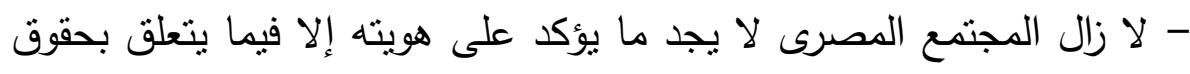

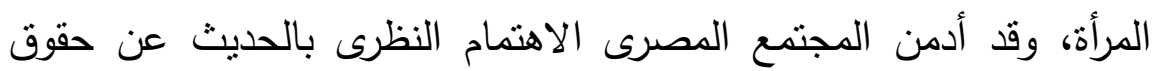

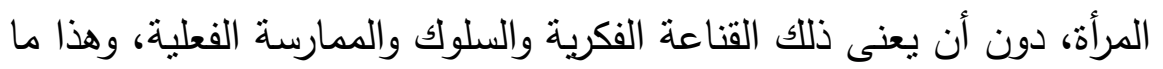
يجعل قضايا المرأة - وعلى مدار التاريخ- تنتهد صعودًا وهبوطًا، وانتكاسات

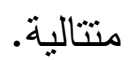


- يوضح مجمل النتائج أن ثمة تغيراً حدث فى الدجمع يمكن رصده، غير أنه

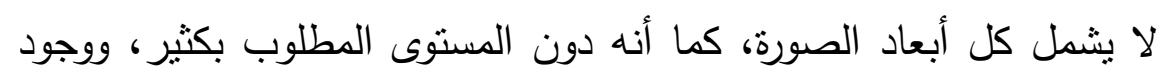

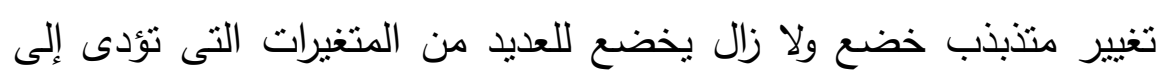
حدوث انتكاسات.

- ورغم وجود قوانين الزواج المبكر وعدم الحرمان من الميراث، وحق المرأة فى نولى المناصب بدون استثناء، وحقها المساوى فى التعليم والعمل ونجاحها

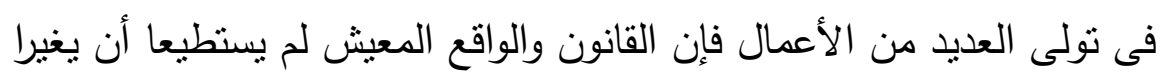

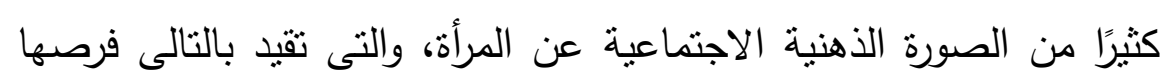
وحقوقها التى حصرها فى إطار هذه الصورة.

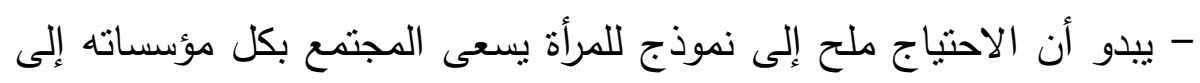

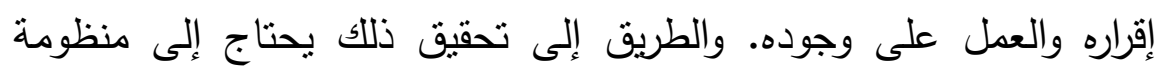

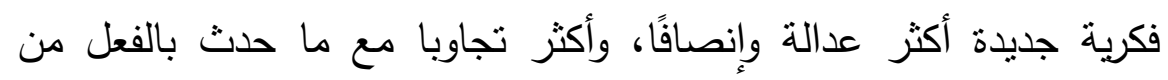

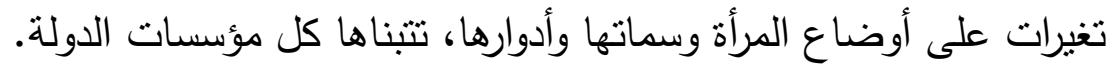

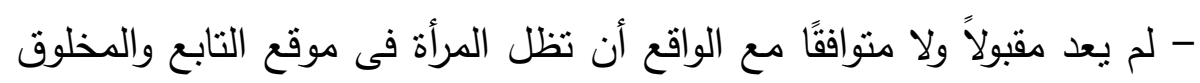

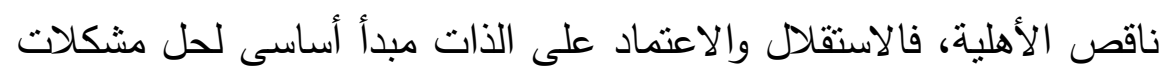

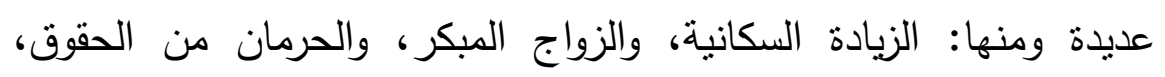
والمعاناة من كل أشكال الفقر المادى والمعنوى.

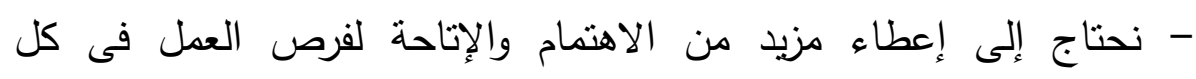

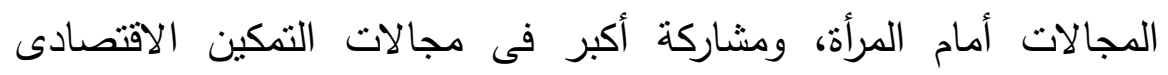

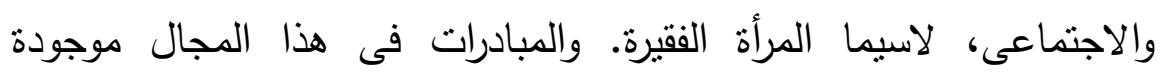
بالفعل، والسؤال حول إمكانيات التغطية الجغرافية والعائد والأثر الفعلى. لألئراء. 
- قد يحدث تغيير عن طريق النتريع والقانون، إلا أن العمل على تغيير الفكر

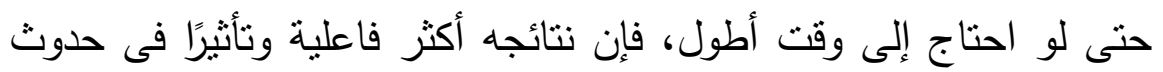

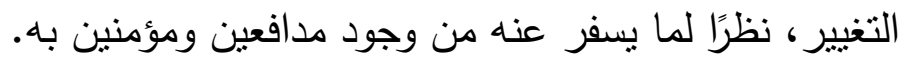

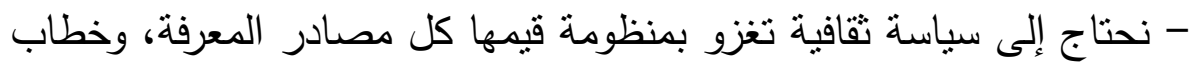

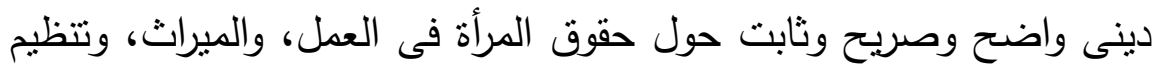
النسل، والوالدية المسئولة، وسن الزواج، وتتظيم الزواج والطلاق، وما يتعلق

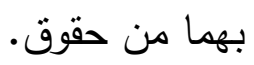
- نحتاج إلى نموذج جديد لتتشئة الفتاة يقوم على تتمية الاستقلال، والاعتماد على الذات، والقدرة على مواجهة المواقف الصعبة، ومحورية العمل فى حياة الإنسان، وأهمية اكتساب المهارات فى شتى المجالات.

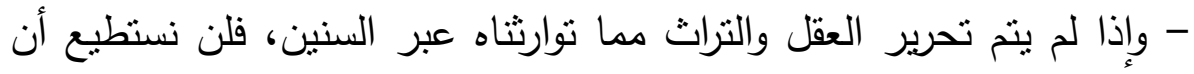
نتعامل مع المرأة كمخلوق مساو كامل الأهلية.

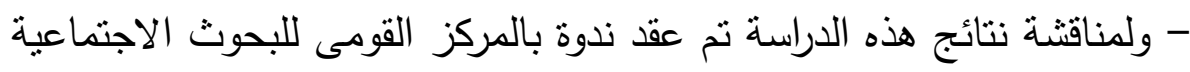

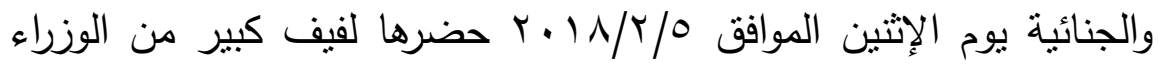
السابقين، وأعضاء وعضوات، مجلس الثعب، وأساتذة الجامعات والكتَّاب. كما رأست الندوة السيدة غادة والى وزيرة التضامن، ورحبت الأستاذة الدكتورة سعاد عبد الرحيم بالحضور ، وركزت على الأهمية المعلقة على هذه الدراسة.

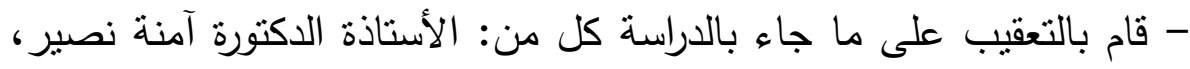

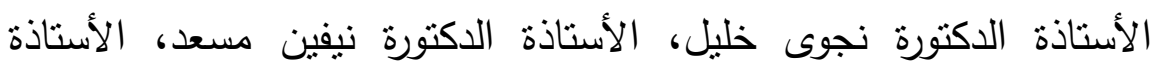

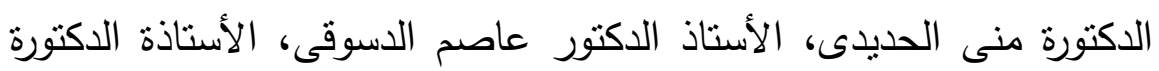

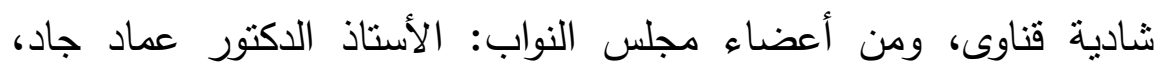

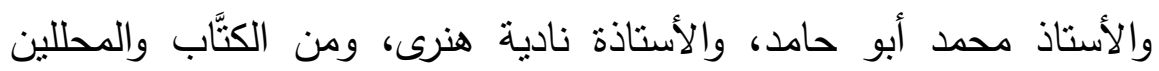
السياسيين: الأستاذ سمير مرقس، والأستاذ عادل نعمان. 


\section{اشتملت هذه التعقيات على العديد من القضايا التى يمكن إجمالها}

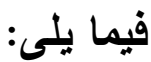

- تأثر الصورة الذهنية الاجتماعية عن المرأة المصرية بالموروث الثقافى الذى

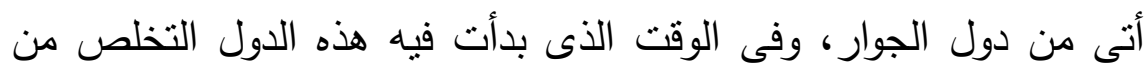
الماضى رسَّخوا لدينا هذه الضبابية.

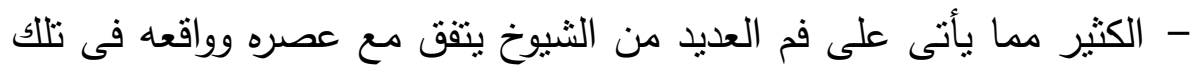
الأيام، ولكن ذلك لا يستدعى أن نظل نستخدمه إلى آخر الزمان التمان.

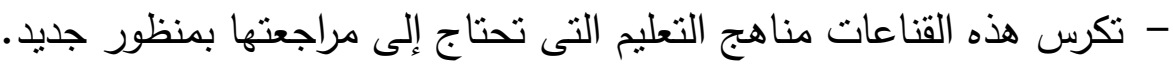

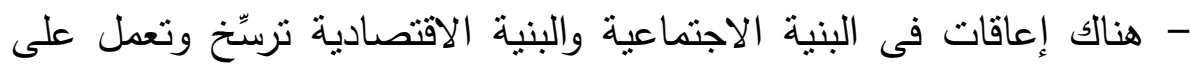
استمرار هذه الثقافة ومثالها: الموقف من الإنجاب باعتباره مصدر دخل للأسرة، ومثكلات المبراث وارتباطها بالحفاظ على دمنلكات الأسرة.

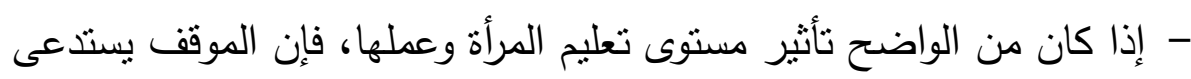
الاهتمام بتيسير فرص العمل للمرأة وبث قيم الاتجاه إلى نموذج المرأة

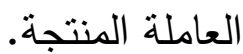

- هناك خلل فى العلاقة بين البنية التشريعية والبنية الدستورية.

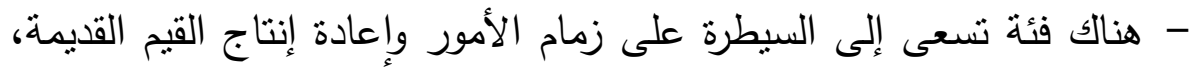

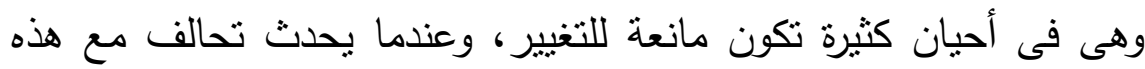

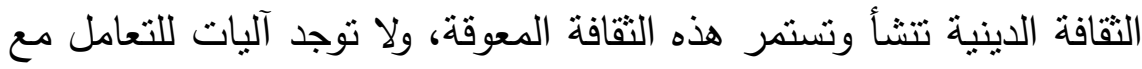
هذه الفئات.

- يسهم الإعلام والتعليم فى تهميش المرأة.

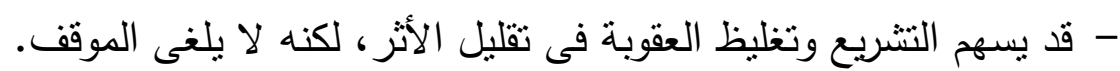

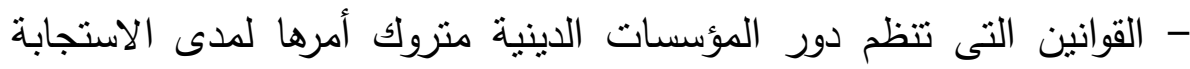

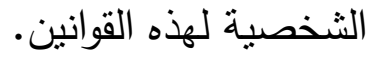


- تتقية الخطاب الدينى، حيث لا يوجد توصيف وظيفى واضح لمعالم هذه

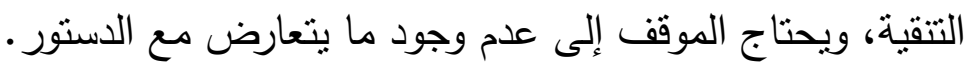
- نعانى ومازلنا من تتاول العديد من الموضوعات، وعندما تتصادم الآراء يغلق الموضوع وكأنه لم يثر، وتظل القضايا هكذا دون حسم على الإطلاق. - المرأة المصرية كثيرا ما تكون ضد حقوقها، بل تمنع كل ما من شأنه الارتقاء بقيمتها والتمتع بحقوقها. - النطبيق المتجرد للقانون باب لتغيير الثقافة.

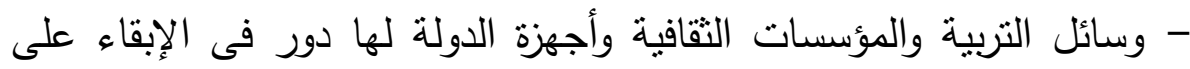

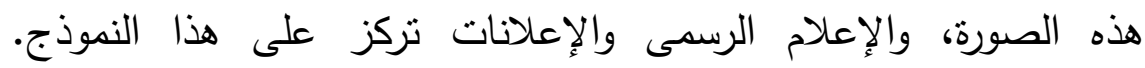
والمسئولية كبيرة على وزارة الثباب ووزارة الثقافة فى هذا الثنأن. - ليس لدينا خطة طويلة المدى لإعادة تتشئة الأبناء والجيل الجديد.

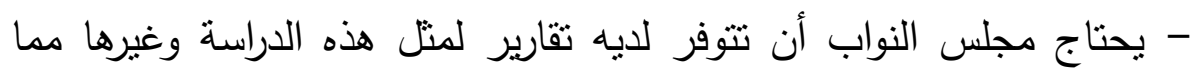

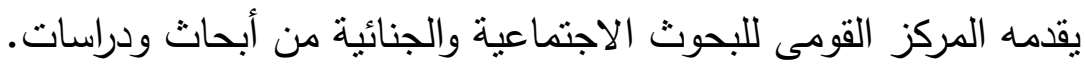

\section{أسفرت مناقشات الندوة عن المقترحات التالية:}

- أن تكون البنية التتريعية على مستوى البنية الدستورية. ما يعنى: * غربلة القوانين لتكون متسقة مع الدستور • * * التطبيق الكامل لدولة القانون وإرساء دعائم المواطنة. * استعادة المواطن الثقة فى القانون كطريق للحصول على الحق، وذلك لكاهل بالتخلى تماما عن الجلسات العرفية، وتحقيق العدالة الناجزة، والتخلص من

$$
\text { البيروقراطية وتعقيد الإجراءات. }
$$

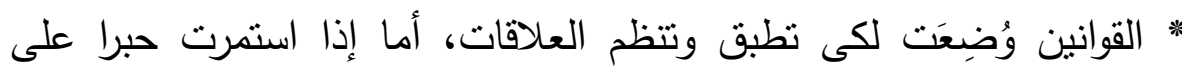

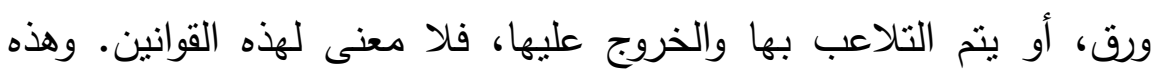
مهمة وزارة العدل، والمجلس القومى للمرأة، والجمعيات الأهلية الحقوقية. 
* تخصيص مكاتب محاماة لمساعدة المرأة فى قضاياها، لاسيما ما يتعلق

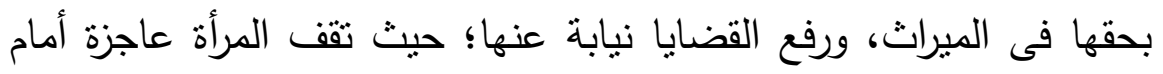

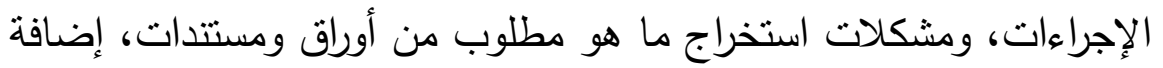

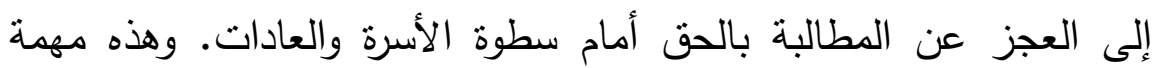
أساسية للمجلس القومى للمرأة. - تغيير الصورة الذهنية الاجتماعية عن المرأة وتحرير العقل مما عَلِقَ به من موروث تقافى. وهذه مهمة مباشرة لوزارة التقافة وقطاعاتها (المجلس الأعلى لئى للصحافة، والهيئة الوطنية للإعلام)، هذا بالإضافة إلى المسئولية الكبيرة

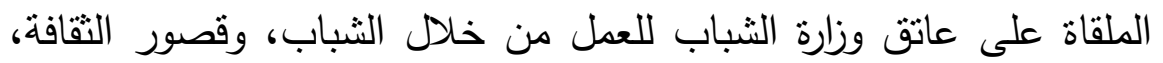

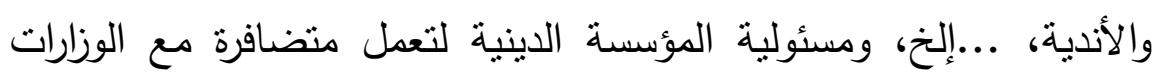
السابقة لتغيير هذه الصورة. - توصيف وتحديد واضح لما هو مطلوب باتجاه تتقية الخطاب الدينى، وآليات التطبيق لما يحتويه.

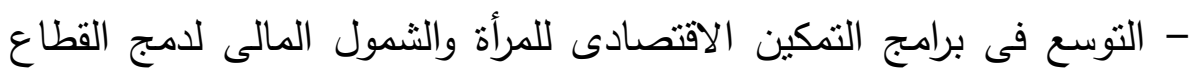

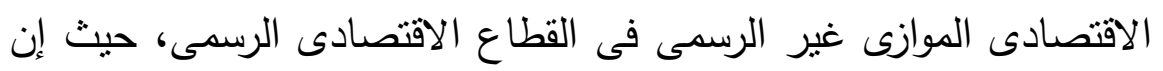
• . لوزارة التضامن فى تحقيق هذا الهدف، لاسيما ولديها إسهام فاعل فى مجال

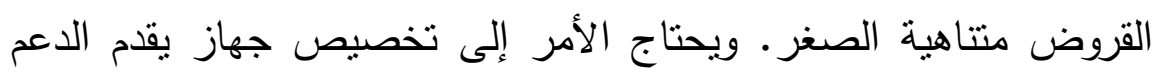

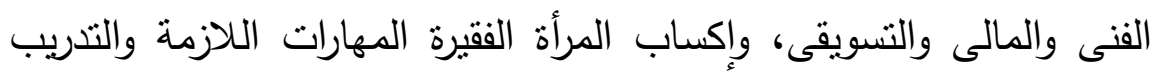
الكافى. - (الكى - على وزارة التربية والتعليم أن تبدأ من الآن فى وضع خطة طويلة الأجل

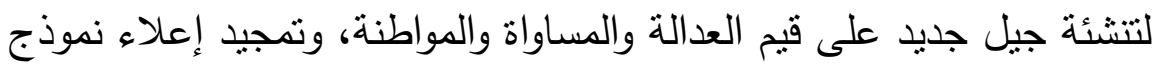

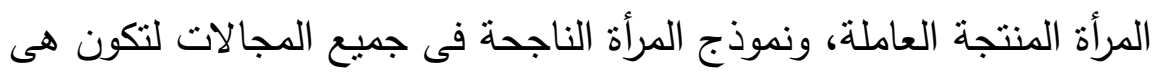




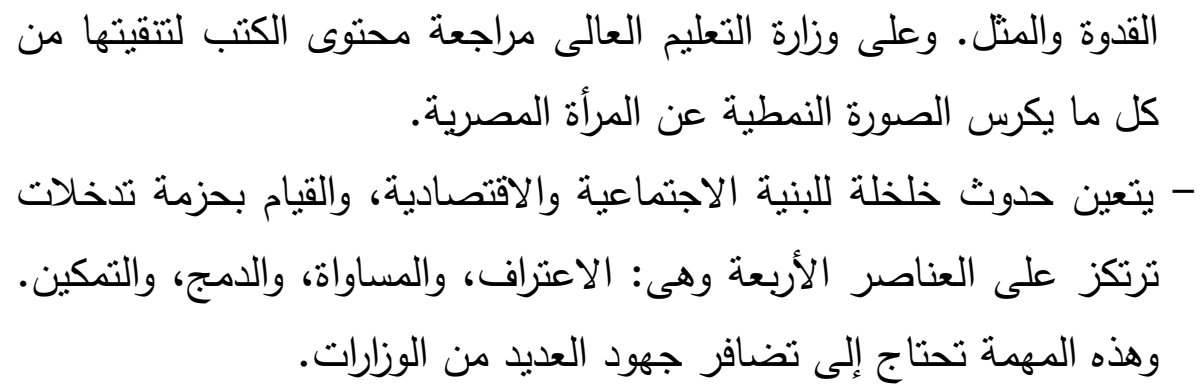

Abstract

MENTAL IMAGE ABOUT THE EGYPTIAN WOMEN

\section{Nadia Halim}

The aim of this research is studying the mental image of the Egyptian women. The data was collected from a representative sample composed of 3000 people males and females from 18 years old +

The dimentions that have been studied are: traits, roles, family relations, and interactions, rights and ability for change. 
$r$. 